\title{
Influence of Good Corporate Governance Implementation on Profit Management: A Research Proposal
}

\author{
*Agus Parhan Saepul Anwar ${ }^{1}$, Ana Yuliana Jasuni ${ }^{2}$ \\ ${ }^{1}$ Management Study Program, Faculty of Business and Humanities, Nusa Putra University, Indonesia \\ ${ }^{2}$ Management Study Program, Faculty of Business and Humanities, Nusa Putra University, Indonesia \\ "Corresponding author.Email:agus.parhan_mn18@nusaputra.ac.id
}

\begin{abstract}
This research aims to see how good corporate governance affects profit management. The audit committee (X1), independent commissioners (X2), institutional ownership (X3), and managerial ownership (X4) are the dependent variables, whereas the audit committee (X1), independent commissioners (X2), institutional ownership (X3), and managerial ownership (X4) are the independent factors (X4). Using a deliberate sampling technique, the population in this research is banking enterprises listed on the Indonesia Stock Exchange (IDX) from 2016 to 2020. The study employs basic assumption tests such as normality, multicollinearity, autocorrelation, and heteroscedasticity, as well as multiple linear regression analysis.
\end{abstract}

Keywords: Good Corporate Governance, Earnings Management, audit committee, independent board of commissioners, institutional ownership, managerial ownership.

\section{INTRODUCTION}

Not only did the Covid-19 pandemic have a negative impact, but it also posed a threat to the health sector. The Covid-19 pandemic also had an economic impact. It substantially impacts the organization's financial state because it is a driving sector. In the thick of a pandemic, we are working to improve the company's financial situation.

The income statement and balance sheet are financial papers used to evaluate a company's financial health [1]. Third parties can utilize financial statements to get insight into a business's financial health and performance. The data relates to a business's financial situation, performance, and changes in financial position, and it may be used to aid a wide variety of individuals in making financial choices. [2].

Profit is an essential component of the financial statements to assess management success. For evaluating management's performance or accomplishments, earnings data is critical. Apart from earnings information, investors and other interested parties utilize the rate of return and success indicators to measure the efficiency of using funds incorporated in the company [3].
Because of the information asymmetry from the internal party, investors should pay more excellent pay close attention to earnings data as a gauge of business performance [4]. It will provide managers with an incentive to alter earnings data to display profits; earnings management is a method of maximizing profits [5]. One of the aspects that could affect the company's earnings management plan is solid corporate governance [6].

The Cadbury Committee, in its report known as the Cadbury Report, coined the term "good corporate governance" in 1992. The Cadbury Committee defines corporate governance as "directly controlling a firm to achieve a balance of power and authority in terms of shareholder and stakeholder accountability [7].

Corporate governance is required to regulate the behavior of company executives so that they do not act solely for their gain. Corporate governance aims to balance the interests of firm owners and executives. The idea of implementation indicators has been around for quite some time. Corporate governance is exhibited by auditors, audit committees, management, ownership of institutional, and the independent commissioners-to-management ratio [8]. 


\subsection{Research Problem Formulation}

Because reported figures do not reflect actual situations, earnings management is one of the reasons financial statements may lose their credibility. One of the issues that could influence earnings management methods, according to some academics, is a lack of well-implemented corporate governance. The conduct of managers who do earnings management can be reduced by establishing solid corporate governance [9].

\subsection{Research Objectives}

1) A study is being carried out to see how managerial ownership affects earnings management.

2) Institutional ownership's effect on earnings management

3) Examining how the independent commission affects profit management.

4) Examining the Independent Audit Committee's impact on profit management.

\section{LITERATURE REVIEW}

\subsection{Financial statements}

Financial statements record a business's current assets, liabilities, and capital. Financial statements are intended to demonstrate a company's financial condition, performance, and changes in financial position. This financial report is beneficial in making selections for interested persons [10].

Investors can assess, quantify, and monitor the amount to which agents seek to enhance their wellbeing using financial data provided by agents and create a framework for compensating agents based on performance [11].

\subsection{Agency Theory}

The origins of agency theory may be traced back to a conflict of interest caused by a mismatch of aims between the principal and the agent [12].

\subsection{Earnings Management}

Earnings management is a manipulation carried out by managers on accounting variables in financial statements to achieve specific goals related to earnings reporting [13].

According to [14], Earnings Management Strategy can be done with several patterns consisting of:

a) Take a bath. The company's organizational troubles or restructuring will cause management to record losses at this time in order to show profits afterward.

b) Income minimization. Companies choose this pattern in a period of high profitability or when trying to protect themselves from foreign competition by reducing profits for specific purposes, for example, avoiding taxing too much.

c) Income maximization. This pattern increases profits for specific purposes, such as getting bonuses and avoiding debt contract violations.

d) Income smoothing. To make the company's profits appear consistent, the firm uses dropping and increasing profits.

\subsection{Good Corporate Governance}

Corporate governance is a term that refers to the set of rules that control how owners, creditors, the governance, employees, managers, and other internal and external stakeholders interact, as well as the framework that leads and governs the organization to maximize shareholder value [15].

The four pillars of sound corporate governance examined in this study were audit committees, management, ownership of institutional, and independent commissioners-to-management ratio. The Board of Directors, the Commissioners' Board, committees, and work units compose the company's corporate governance structure. In essence, it is a form of community-based government.

a) Institutional ownership refers to the ownership of businesses by institutional investors, including insurance companies, financial institutions (banks, financial corporations, credit), pension funds, investment banking, and other businesses in this category. Because institutional ownership supports more suitable growth in supervision, it has a substantial impact on monitoring management. However, institutional ownership's power as a supervisory agency is limited due to their significant capital market investments [16].

b) An Independent Commissioner is someone who is not influenced in any way. According to the National Committee on Policies and Governance (2012), the following are typical examples: Independent commissioners are members of the board of commissioners who are not affiliated with management. The controlling shareholders and other members of the board of commissioners have no business or other relationships that would preclude them from acting entirely independently and in the firm's best interests [17]. Independent commissioner involvement is necessary because transactions frequently involve conflicts of interest 
that jeopardize the interests of public shareholders and other stakeholders.

According to FSAR No 55/POJK.03/2016 According to Article 24 of the Implementation of Governance for Commercial Banks, independent commissioners shall comprise at least $50 \%$ of the entire membership of the commissioner's board. [18].

c) Managerial ownership refers to the percentage of a company's shares owned by management; in this situation, management refers to the company's management (directors, managers, and employees) [19]. Managerial ownership has proven to be an effective mechanism for reducing managers' agency problems by aligning managers' interests with shareholders so that managers do not manipulate earnings to benefit themselves. [20].

d) To ensure the accuracy of management's financial reporting, an audit committee must be formed. An audit committee is a group of persons overseeing the audit. According to the Financial Authority's Circular Letter 16/SEOJK.05/2014, insurance companies must keep a Digital Repository of 25 audit committees and a risk monitoring committee of at least three persons. Consequently, the researcher incorporated the audit committee in the corporate governance guidelines [21].

\subsection{Thinking Framework}

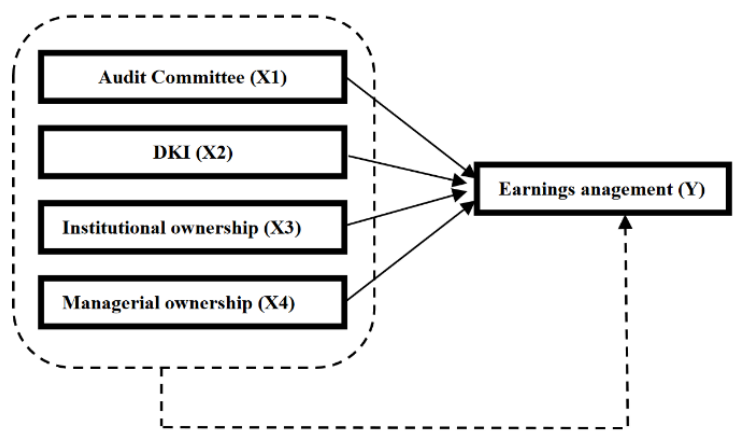

Figure 1. Framework Research

The committee of audit, board of independent commissioners, ownership of institutional, and ownership of management were all used in this study, as described by the theoretical foundation and prior research. Earnings Management is expected to be changed. The following is the shape of the Thinking frame image:

\subsection{Hypothesis}

Using the theoretical framework outlined above, the author attempts to reach the following conclusion on the research hypothesis:
H1: Managerial ownership has a (+) effect on earnings management.

H2: Institutional ownership has a (+) effect on earnings management.

H3: Independent commissioners have a (+) effect on profit management.

H4: An independent audit committee has a (+) effect on earnings management.

\section{RESEARCH METHOD}

The dependent variable and the independent variable were the variables in this investigation. The audit committee is the dependent variable (X1), independent commissioners (X2), institution ownership (X3), and managerial ownership (X4), whereas the independent variables are a committee of audit (X1), commissioners of independent (X2, ownership of institutional (X3), and ownership of managerial (X4).

\subsection{Dependent Variables}

Earnings management is the dependent variable, an action made by specified individuals, usually firm management, to manage profits for specific purposes and objectives. The Modified Jones Model is employed to determine earnings management in this study.

Because controlling revenue is more accessible than managing revenue through discretionary revenue recognition on credit sales, the Jones model implies that any changes in credit sales throughout the event period are ascribed to earnings management. There is an option for a cash sale [22]. The goal of applying management discretion to income is to prevent the risk of miscalculating discretionary accruals using the Jones Model premise [23].

1) Using the following formula to calculate total accrual (TAC), which is net income minus operating cash flow in year $\mathrm{t}$ :

$$
\text { TAC = NIit }- \text { CFOit }
$$

Furthermore, The total accrual (TA) is estimated as follows using Ordinary Least Squares:

$$
\frac{\text { TAit }}{\text { Ait }-1}=\beta 1+\left(\frac{1}{\text { Ait }-1}\right)+\beta 2\left(\frac{\text { Revit }}{\text { Ait }-1}\right)+\beta 3\left(\frac{\text { PPEit }}{\text { Ait }-1}\right)
$$

2) Nondiscretionary accruals (NDA) are calculated using the same regression coefficient as in the previous formula:

$$
\begin{array}{r}
\text { NDAit }=\beta 1+\left(\frac{1}{\text { Ait }-1}\right)+\beta 2\left(\frac{\text { Revit }}{\text { Ait }-1}-\frac{\text { Recit }}{\text { Ait }-1}\right) \\
+\beta 3\left(\frac{\text { PPEit }}{\text { Ait }-1}\right.
\end{array}
$$


3) Finally, as a gauge of earnings management, the following approach is employed to determine discretionary accruals (DA):

DAit $=\left(\frac{1 T \text { Ait }}{\text { Ait }-1}\right)-N D A i t$

\subsection{Independent Variables}

The measurement of four independent variables [10] is as follows:

\section{1) Audit Committee (X1)}

Share. The audit committee's role is to oversee management (agents) to ensure they do not engage in self-serving behavior; hence the audit committee must ensure higher quality financial reporting for shareholders. The audit committee is evaluated in this study in the following ways:

Audit Committee $=\sum$ Audit Committee member

\section{2) Independent Board of Commissioners (X2)}

Independent commissioners are determined using a ratio scale that considers that the percentage of the commissioner's board is not corporate employees across all board sizes. The following is the formula for computing these variables:

$D K I=\frac{\text { Independent Board of Commissioners }}{\text { Total Board of Commissioners }}$

\section{3) Institutional Ownership (X3)}

By using the percentage indicator of the number of institutional ownership shares of all outstanding share capital with the following formula, institutional ownership is referred to as a sophisticated investor because it has a great deal of knowledge and experience in investing in a company, making it difficult to be fooled by management actions:

$K I=\frac{\text { Numbe of institutional shares }}{\text { Total Shares outstanding }}$

\section{4) Managerial Ownership (X4)}

The corporation in question, as well as its affiliates. Shares owned by management or subsidiaries are referred to as managerial ownership. A ratio scale is used to quantify management ownership variables; the formula for measuring these variables is as follows:

$K M=\frac{\text { Numbe of managerial sharesi }}{\text { Total Shares outstanding }}$

\subsection{Population and Sample}

For the 2016-2020 time frame, the sample is a bank listed on the BEI (Indonesian Stock Exchange) (including those whose shares are fixed, their shares have just been included in the calculation of the IDX and their shares are out of the IDX). The company publishes an annual report for 2016-2020 and has data on corporate governance. A positive discretionary accruals value in 2016-2020 or companies with a negative DA value is not used.

\subsection{Analysis Method}

This study's data analysis procedures Multiple linear regression is a technique for determining how each independent variable affects the dependent variable:

$$
\mathrm{DA}=0+1 \mathrm{KA}+2 \mathrm{DKI}+3 \mathrm{KI}+4 \mathrm{KM}+\mathrm{r}
$$

Description:

- DA = Discretionary Accruals

- $\mathrm{c}=$ Constant'

- $\mathrm{KA}=$ Audit Committee

- DKI = Commissioners of Independent Board

- $\mathrm{KI}=$ Ownership of Institutional

- $\mathrm{KM}=$ Ownership of Managerial

- $1 \ldots .3=$ Coefficient X1 ....X3

- $\mathrm{r}=$ Error

The classical assumption tests were then performed, which included the normality test using graphical analysis and the Kolmogorov-Smirnov (KS) statistical test, the multicollinearity test (where no multicollinearity was found if VIF 10 and the tolerance value was > 0.1), heteroscedasticity test using the Glejser test, and autocorrelation test using the DurbinWaston test.

The simultaneous test $(F)$ is then used to see if the multiple linear regression model can predict profits management's dependent variable. If the significance threshold is more than 0.05 , the regression model cannot forecast profit. If the partial test's significance level is more significant than 0.05 , the independent variable does not influence the dependent variable. The coefficient of determination measures how well one independent variable explains another. There is a simultaneous determination coefficient (R2) as well as a partial determination coefficient $\left(\mathrm{R}^{2}\right)$ in this study $\left(\mathrm{R}^{2}\right)$.

\section{EXPECTED RESULTS}

The goal of the research plan is to investigate how healthy banking businesses implement good corporate governance in order to minimize earnings 
manipulation. Audit committees, independent commissioners, institutional ownership, and management ownership are all markers of effective corporate governance that the supervisory body, OJK, monitors (Financial Services Authority).

\section{REFERENCES}

[1] S. Husnan, Manajemen Keuangan. Universitas Terbuka, 2017.

[2] D. Agustia, "Pengaruh Faktor Good Corporate Governance, Free Cash Flow, dan Leverage Terhadap Manajemen Laba.," Jurnal Akuntansi dan Keuangan, vol. 15, no. 1, pp. 27-42, 2013, doi: 10.9744/jak.15.1.2742.

[3] R. Pranita, "Mekanisme Good Corporate Governance dan Nilai Perusahaan . Lembaga Penelitian dan Penulisan Ilmiah ALQI, 2018.

[4] V. Herawaty, "Peran Praktek Corporate Governance Sebagai Moderating Variable dari Pengaruh Earnings Management Terhadap Nilai Perusahaan. Peran Praktek Corporate Governance Sebagai Moderating Variable Dari Pengaruh Earnings Management Terhadap Nilai Perusahaan," vol. 10, no. 2, pp. 97-108, 2008, doi: 10.9744/jak.10.2.PP.97-108.

[5] Z. Fanani, "Karakteristik Perusahaan Dan Corporate Governance Terhadap Manajemen Laba: Studi Analisis Meta," Jurnal Keuangan dan Perbankan, vol. 18, no. 2, pp. 181-200, 2014.

[6] F. S. Kawatu, "Mekanisme Tata Kelola Terhadap Nilai Perusahaan Dengan Kualtas Laba Sebagai Variabel Intervening," Jurnal Keuangan dan Perbankan, vol. 13, no. 3, pp. 405-417, 2009, [Online]. Available: http://jurnal.unmer.ac.id/index.php/jkdp/ article/download /1089/732.

[7] Y. Mangkusuryo and A. W. Jati, "Pengaruh Mekanisme Good Corporate Governance Terhadap Manajemen Laba," Jurnal Reviu Akuntansi dan Keuangan, vol. 7, no. 2, p. 1067, 2017, doi: 10.22219/jrak.v7i2.20.

[8] N. Hidayati and H. Sunaryo, "Dampak Corporate Governance terhadap Keputusan Dividen (Literature Review pada negaranegara Asia, Australia dan Afrika)" Jurnal Keuangan dan Perbankan, vol. 20, no. 1, pp. 32-41, 2016, doi: 10.26905/jkdp.v20i1.146.

[9] S. Melati Sihombing, "Pengaruh Good Corporate Governance terhadap Manajemen
Laba pada Perusahaan Manufaktur yang terdaftar di Bursa Efek Indonesia Tahun 20132017" vol. 01, 2021.

[10] A. S. Putri, "Pengaruh Good Corporate Governance Terhadap Praktik Manajemen Laba Perusahaan," Technobiz Int. J. Bus., vol. 3, no. 2, pp. 15-20, 2020, [Online]. Available: https://ejurnal.teknokrat.ac.id/index.php/tech nobiz/article/view/1077.

[11] H. Hadi Sucipto and U. Umi Zulfa, "Pengaruh Good Corporate Governance, Financial Distress dan Ukuran Perusahaan Terhadap Manajemen Laba," Jurnal Riset Akuntansi \& Keuangan. Dewantara, vol. 4, no. 1, pp. 1-12, 2021, doi: 10.24843/eja.2019.v27.i01.p07.

[12] P. P. Rohmawati, Analisis Pengaruh Good Corporate Governance dan Faktor-Faktor Lainnya Terhadap Manajemen Laba Perusahaan Sektor Asuransi, vol. 18, no. 1. 2020.

[13] H. Herman Sudrajat, "Analisis Mekanisme Good Corporate Governance (GCG) Terhadap Manajemen Laba Dengan Ukuran Perusahaan Dan Rasio Keuangan Sebagai Variabel Intervening Pada Perusahaan Automotif Di Bursa Efek Indonesia (BEI),” 2020.

[14] V. Sherlita and T. F. Jin, "Pengaruh Good Corporate Governance terhadap Kinerja Keuangan," vol. 1, no. 2, pp. 111-120, 2021.

[15] T. Deyan Tiara, K. Karina Mardhatillah, and N. Noviyanti, "The Influence of Good Corporate Governance and Information Asymmetry on Earnings Management (Empirical Study on Manufacturing Companies in the Basic Industry and Chemicals Listed on the IDX)," vol. 1, no. 2, pp. 333-341, 2021.

[16] P. Awik Pratiwi, "Analisis Mekanisme Good Corporate Governance (GCG) terhadap Manajemen Laba dengan Ukuran Perusahaan sebagai Variabel Intervening pada Perusahaan Automotif di Bursa Efek Indonesia (BEI).," University Pembangunan Panca Budi Medan, 2019.

[17] F. L. Lolana and S. Dwimulyani, "Pengaruh Good Corporate Governance Terhadap Manajemen Laba Dengan Tax Avoidance Sebagai Variabel Intervening." Pros. Semin. Nas. Pakar, vol. 2, no. Book 2:Sosial \& Humaniora, pp. 6-16, 2019.

[18] Anisa and E. Suryani, "Pengaruh Good Corporate Governance Terhadap Manajemen 
Laba (studi Pada Perusahaan Perbankan Yang Terdaftar Di Bursa Efek Indonesia Periode 2016-2018)" vol. 7, no. 1, pp. 755-763, 2020.

[19] S. I Kadek Kanton Septian, P. I Gede Cahyadi Putra, and A. Ida Ayu Ratih Maunari, "Pengaruh Good Corporate Governance dan Ukuran Perusahaan Terhadap Manajemen Laba Pada Perusahaan Manufaktur," Jurnal Karma, vol. 1, no. 3, pp. 1-8, 2021.

[20] H. Hexana Sri lastanti, "Pengaruh Good Coporate Governance Terhadap Earning Management," vol. 8, 2013.

[21] N. Khoirun Nisa Intan Nurani, Y. Anik Yuliati, and D, "Pengaruh Good Corporate
Governance, Ukuran Perusahaan Dan Kualitas Audit Terhadap Manajemen Laba (Studi Empiris Terhadap Perusahaan Bumn Yang Tercatat Di Bursa Efek Indonesia Periode 2015-2019)," vol. 5, no. 3, pp. 228-252, 2021.

[22] D. Patricia M. Dechow, S. Richard G. Sloan, and S. Amy P Sweeney, "Detecting Earnings Management," Med. J. Aust., vol. 70, 1995, doi: 10.5694/j.1326-5377.1952.tb109167.x.

[23] E. Suyono, "Berbagai Model Pengukuran Earnings Management:," Sustain. Compet. Advantage-7 Feb Unsoed, vol. 7, no. September, pp. 303-324, 2017, [Online]. 